УДК 35.078:681.518

DOI https://doi.org/10.32836/2310-9653-2020-3.13

Я. В. Янсонс, кандидат технічних наук, докторант кафедри парламентаризму та політичного менеджменту Національної академії державного управління при Президентові України

\title{
РОЗВИТОК ПРАВОВОГО МЕХАНІЗМУ ПУБЛІЧНОГО УПРАВЛІННЯ ВПРОВАДЖЕННЯМ ІНСТРУМЕНТІВ ЕЛЕКТРОННОЇ ДЕМОКРАТІЇ
}

\begin{abstract}
Стаття присвячена аналізу механізму правового забезпечення розвитку електронної демократії в Україні в частині формування й імплементації інструментів електронної демократії. Відповідно до Концепиії розвитку електронної демократії в Україні, «інструменти електронної демократії-засоби для забезпечення формування та реалізаиї держсавної політики, розвитку самоврядування шляхом використання інформаційно-комунікаційних технологій у демократичних процесах».

Проаналізовано рівень законодавчого визначення інструментів електронної демократії в національних концептуальних та стратегічних документах. Значного поширення набули такі інструменти електронної демократії, як електронні консультації, електронні петииії, електронні звернення, бюджети участі (громадські бюджети). Визначено особливості еволюиї застосування інструментів електронної демократї державними органами та громадськими організаціями. Встановлено причини повільного розвитку низки інструментів електронної демократії.

Здійснено порівняльний аналіз застосування інструментів електронної демократії в Україні та Європейському Союзі, виокремлено та доведено недоліки, притаманні начіональному правовому механізму розвитку електронної демократії щодо застосування ії інструментів на загальнодержавному, регіональному та місцевому рівнях. Основними вадами правового механізму є: недосконалість його ресурсного забезпечення; відсутність иілісного бачення державою стратегії розвитку електронної демократії як інституиії; переважання розвитку електронних послуг, автоматизації тощо над розвитком інструментів активного залучення громадян до участі у громадсько-політичному житті краӥни.

Обгрунтовано рекомендамії публічним органам влади щодо вдосконалення чинного правового механізму впровадження, застосування та розвитку інструментів електронної демократії.

Ключові слова: публічне управління, правовий механізм публічного управління, електронна демократія, інструменти електронної демократії.
\end{abstract}

Ya. V. Yansons. The legal mechanism development of the public administration by the implementation of electronic democracy tools

The article is devoted to the analysis of the legal support mechanism for the e-democracy development in Ukraine in terms of the formation and implementation of e-democracy tools. According to the Concept for the Development of Electronic Democracy in Ukraine, "e-democracy tools are means to ensure the formation and implementation of state policy, the development of local self-government through the use of information and communication technologies in democratic processes".

The level of legislative definition of e-democracy tools in national conceptual and strategic documents has been analyzed in the paper. Such e-democracy tools as e-consultations, individual and group e-petitions, participation budgets (public budgets) have spread widely. The features of the e-democracy tools way evolution by state bodies and public organizations have been determined. The reasons for the slow development of some e-democracy tools have been identified.

A comparative analysis of the use of e-democracy tools in Ukraine and the EU is carried out. The shortcomings inherent in the national legal mechanism for the e-democracy development in the application of its tools at the national, regional and local levels have been highlighted and proved.

The main disadvantages of the legal mechanism are: imperfection of its resource provision; lack of a holistic vision of the strategy for the e-democracy development as an institution by the state; prevalence of the development trend of electronic services, automation, etc. over the development of tools for actively attracting citizens to participate in the social and political life of the country.

It has found that these shortcomings hinder the development of such tools of e-democracy as: e-voting, e-elections, e-referendum and e-plebiscite.

The recommendations to public authorities on improving the existing legal mechanism for the introduction, application and development of e-democracy tools have been substantiated. The essence of recommendations mentioned above is: the need to develop a number of strategic and conceptual documents of the development e-democracy tools; legislative consolidation of resource support for the development of e-democracy tools as one of the methods for implementing e-democracy in Ukraine.

Key words: public administration, legal mechanism of public administration, e-democracy, e-democracy tools.

Постановка проблеми. Досягнення належного рівня розвитку електронної демократії є однією із цілей формування цифрового суспільства. Реалізація електронної демократії здійснюється, серед іншого, шляхом застосування ії інструментів, які спрямовані насамперед на підвищення рівня участі громадськості в політичному житті країни. Поняття «інструменти електронної демократії» визначено в Концепції розвитку електронної демократії в Україні [1], це «засоби для забезпечення формування та реалізації державної політики, розвитку самоврядування шляхом використання інформаційно-комунікаційних технологій у демократичних процесах». Успішність формування й імплементації інструментів

(C) Я. В. Янсонс, 2020 
електронної демократії залежить від належного функціонування сукупності взаємопов’язаних механізмів електронної демократії (правових, організаційних, фінансових тощо). Усталена практика закордонних країн вказує на те, що загальне регулювання розвитку електронної демократії в органах виконавчої влади покладається на профільне міністерство або інший центральний орган виконавчої влади з відповідним закріпленням пріоритетних напрямів ії розвитку в законодавстві, поряд з іншим, у керівних концептуальних документах Уряду. В Україні таким органом визначено Міністерство цифрової трансформації, головні цілі якого: цифровізувати 100 публічних послуг, 100\% міст під’єднати до мобільного зв'язку й інтернету, навчити 6 млн українців базовим цифровим навичкам, збільшити долю IТ у ВВП країни до 10\%, $100 \%$ державних послуг перевести в онлайн [2].

У Програмі діяльності Уряду № 471 від 12 червня 2020 р. [3] для Мінцифри визначено такі ключові напрями: 1) розвиток адміністративних послуг, їх цифровізація; 2) інформатизація суспільства; 3) сприяння розвитку IT-бізнесу; 4) цифрова грамотність населення тощо. Розвиток інструментів електронної демократії, зокрема створення онлайн-платформи для взаємодії органів виконавчої влади з інститутами громадянського суспільства, забезпечення механізму електронного голосування під час формування складу громадських рад при центральних і місцевих органах виконавчої влади. Включено одне з 10 пріоритетних завдань Мінцифри, що наочно демонструє ставлення виконавчої влади до розвитку електронної демократії у країні. Зазначене чітко виокремлює поточні проблеми, що полягають у приділенні недостатньої уваги питанням розбудови електронної демократії, спонукає до розвідки шляхів формування й удосконалення механізмів iï розвитку.

Актуалізує проблему розвитку електронної демократії й той факт, що низка концептуальних та стратегічних документів із цієї тематики завершують свою дію у 2020 р., тому забезпечення безперервного сталого розвитку сфери, що досліджується, потребує нових редакцій цих актів, серед яких: Стратегія розвитку інформаційного суспільства в Україні, затверджена розпорядженням Кабінету Міністрів України № 386-р від 15 травня 2013 р. (до 2020 р.); Національна стратегія сприяння розвитку громадянського суспільства в Україні на 2016-2020 рр., затверджена Указом Президента України № 68/2016 від 26 лютого 2016 р. (завершується у 2020 р.); Концепція розвитку електронної демократії в Україні та план заходів щодо іiі реалізації, затверджені розпорядженням Кабінету Міністрів України № 797-р від 8 листопада 2017 р., зі змінами від 5 лютого 2020 р. (до 2020 р.); Концепція розвитку електронного урядування в Україні, затверджена розпорядженням Кабінету Міністрів України № 649-р від 20 вересня 2017 р., зі змінами від 5 лютого 2020 р. (виконання заходів розраховане до 2020 р.); Концепція розвитку цифрової економіки та суспільства України на 2018-2020 рр., затверджена розпорядженням Кабінету Міністрів України № 67-р від 17 січня 2018 р., зі змінами від 4 грудня 2019 р. (до 2020 р.) тощо.

Аналіз останніх досліджень і публікацій. Дослідження правових аспектів розвитку інструментів електронної демократії різною мірою висвітлено в роботах А. Семенченка, І. Жиляєва, В. Дрешпака [4; 5], Н. Грицяк, С. Соловйова [6].

Водночас питання правового механізму публічного управління розвитком електронної демократії в частині вдосконалення електронних інструментів потребує додаткової уваги та має як теоретичну, так і практичну цінність 3 огляду на необхідність модернізації чинного законодавства.

Мета статті - оцінка стану правового механізму публічного управління впровадженням інструментів електронної демократії, здійснення порівняльного аналізу з відповідними механізмами Свропейського Союзу (далі - СС), формування на його основі науково обгрунтованих рекомендацій органам влади України щодо вдосконалення правового механізму реалізації інструментів електронної демократії.

Виклад основного матеріалу. Рушійною силою електронної демократії $є$ конвергенція механізмів традиційної демократії та можливостей інформаційно-комунікаційних технологій. Але будь-які вдосконалення, суто в технічному плані, без принципових змін у комунікаційній політиці влади щодо громадян, демократизації суспільного життя загалом, активної позиції громадян, розбудови громадського й інформаційного суспільства не здатні забезпечити належний розвиток та посилити демократію, демократичні інститути. Упровадження технологічних аспектів у демократичні процеси має на меті лише розширити доступні традиційним демократичним процесам можливості, залучити в ці процеси якомога більше свідомих представників суспільства. Водночас базовими речами мають бути демократичні цінності, верховенство права та захист прав людей, які, у свою чергу, мають бути поєднані з технологічною складовою частиною.

Низка міжнародних концептуальних документів містять настанови щодо використання конкретних інструментів для розбудови електронної демократії. Так, Рекомендації Комітету міністрів Ради Свропи [7] визначають інструментарій електронної демократії, виходячи з наявних проблем, як-от низькі показники явки під час виборів, скорочення рівня легітимності, збільшення розривів між державною владою та громадськістю, зниження зацікавленості молоді щодо політичних процесів, недостатня прозорість в інформації та процесах тощо. Для вирішення вказаних проблем пропонується використання електронних рішень у вигляді електронної участі, електронного парламенту, електронних звернень, електронних консультацій, електронних форумів, електронних ініціатив. Також зазначається, що:

- вибір конкретних інструментів має відображати демократичні, гуманітарні, соціальні, етнічні та культурні цінності;

- електронна демократія повинна враховувати реалії нинішнього інформаційного та комунікаційного суспільства і надавати інструменти, схожі з тими, які люди використовують у повсякденному житті; 
- інструменти електронної демократії повинні забезпечувати громадянам доступ до участі в повсюдному, безперервному демократичному процесі, доступ до якого цілодобовий, у будь-якому місці перебування;

- безперервне навчання навичок, необхідних для використання інструментів електронної демократії, має бути запропоновано громадськими навчальними інститутами і роботодавцями, зокрема й у формі електронного навчання для користувачів.

На загальнонаціональному рівні перелік пріоритетних інструментів електронної демократії визначено в таких законодавчих актах, як: розпорядження Кабінету Міністрів України № 259-р від 5 травня 2003 р. «Про затвердження Концепції формування системи національних електронних інформаційних ресурсів»; розпорядження Кабінету Міністрів України № 649-р від 20 вересня 2017 р. «Про схвалення Концепції розвитку електронного урядування в Україні»; Указ Президента України № 683/2002 від 1 серпня 2002 р. «Про додаткові заходи щодо забезпечення відкритості у діяльності органів державної влади»; постанова Кабінету Міністрів України № 1302 від 29 серпня 2002 р. «Про заходи щодо подальшого забезпечення відкритості у діяльності органів виконавчої влади», зі змінами від 5 лютого 2020 р.; розпорядження Кабінету Міністрів України № 386-р від 15 травня 2013 р. «Про схвалення Стратегії розвитку інформаційного суспільства в Україні»; розпорядження Кабінету Міністрів України № 797-р від 8 листопада 2017 р. «Про Концепцію розвитку електронної демократії в Україні та плану заходів щодо ії реалізації», зі змінами від 5 лютого 2020 р.; розпорядження Кабінету Міністрів України № 67-р від 17 січня 2018 р. «Про Концепцію розвитку цифрової економіки та суспільства України на 2018-2020 рр.», зі змінами від 4 грудня 2019 р.

У Концепції розвитку електронної демократії в Україні визначено, що «найбільш поширеними інструментами електронної демократії, що застосовуються сьогодні в Україні як на загальнодержавному, так і на місцевому рівні, є електронні консультації, електронні петиції, електронні звернення, бюджети участі (громадські бюджети). У Концепції підкреслюється актуальність створення ресурсів для оприлюднення наборів даних у формі відкритих даних, зокрема з використанням електронних платформ, наприклад «Громадянське суспільство і влада», «Розумне місто» чи «Сдина система місцевих петицій», які поєднують у собі кілька електронних інструментів участі».

На основі дослідження зазначених вище концептуальних та стратегічних документів, що визначають формування, упровадження й удосконалення інструментів електронної демократії, здійснено систематизацію її інструментів, зазначена важливість цих інструментів для органів влади, що відображає відсутність єдиної політики держави стосовно розвитку електронних інструментів (табл. 1).

Інструменти електронної демократії, що визначені в законодавстві Україні

Таблиця 1

\begin{tabular}{|c|c|c|c|c|}
\hline & \multicolumn{4}{|c|}{ Концептуальні та стратегічні документи } \\
\hline $\begin{array}{c}\text { Назва електронного } \\
\text { інструменту }\end{array}$ & $\begin{array}{c}\text { Концепції розвитку } \\
\text { цифрової економіки } \\
\text { та суспільства України } \\
\text { на 2018-2020 рp. } \\
\end{array}$ & $\begin{array}{c}\text { Концепція } \\
\text { електронного } \\
\text { урядування } \\
\text { в Україні } \\
\end{array}$ & $\begin{array}{c}\text { Концепція розвитку } \\
\text { електронної } \\
\text { демократії в Україні }\end{array}$ & $\begin{array}{c}\text { Стратегія розвитку } \\
\text { інформаційного } \\
\text { суспільства } \\
\text { в Україні } \\
\end{array}$ \\
\hline електронні консультації & + & - & + & + \\
\hline електронні звернення & - & + & + & + \\
\hline електронні петиції & + & + & + & + \\
\hline $\begin{array}{c}\text { бюджети участі } \\
\text { (громадські бюджети) }\end{array}$ & - & + & + & + \\
\hline електронне голосування & + & - & + & + \\
\hline електронний плебісцит & - & - & + & + \\
\hline $\begin{array}{l}\text { електронний } \\
\text { референдум }\end{array}$ & + & - & + & + \\
\hline $\begin{array}{c}\text { електронний виборчий } \\
\text { процес }\end{array}$ & + & + & + & + \\
\hline електронна участь & + & + & + & + \\
\hline $\begin{array}{c}\text { електронне обговорення } \\
\text { проєктів норматив- } \\
\text { но-правових актів }\end{array}$ & - & + & - & - \\
\hline е-парламент & + & - & - & + \\
\hline е-правосуддя & + & - & - & - \\
\hline $\begin{array}{c}\text { е-медіація (досудове } \\
\text { врегулювання спорів) }\end{array}$ & + & - & - & - \\
\hline е-політичні кампанії & + & - & - & - \\
\hline е-опитування & + & - & - & - \\
\hline
\end{tabular}

Джерело: складено автором. 
За результатами аналізу автор дійшов висновку щодо відсутності взаємоузгодженості зазначених вище документів щодо систематизації та пріоритетності інструментів електронної демократії. Також значна увага приділена таким інструментам, як: електронні звернення, електронні петиції, електронні консультації, «відкритий бюджет» («громадський бюджет»). Мало уваги приділяється: електронним голосуванням, електронному референдуму, електронному плебісциту й електронному виборчому процесу загалом. У Звіті про використання інструментів електронної демократії органами державної влади та місцевого самоврядування Державної служби статистики за 2019 р. [8] також зазначається, що основними інструментами електронної демократії для органів влади є: електронні звернення, електронні петиції, електронні консультації, «відкритий бюджет» («громадський бюджет»). Інші інструменти протягом 2019 р. органами влади не використовувалися.

Зазначене свідчить, що натепер немає бюджетних ресурсів на розвиток інструментів електронної демократії в органів влади, мотиваційних ресурсів вистачає на підтримку вже реалізованих інструментів, а рівень цифрової грамотності та навченості державних службовців не дозволяє розвивати електронні інструменти належним чином. Аналіз статистичних даних «Звіту про використання інструментів електронної демократії органами державної влади та місцевого самоврядування» Державної служби статистики за 2019 р. дозволив виокремити такий недолік, як відсутність об'єктивної системи контролю за даними, отриманими від органів влади. Незважаючи на те, що технічно такий контроль може бути реалізований, натепер інформація від органів влади отримується лише за запитом і у формі анкетування.

Низка нормативно-правових документів України містять положення щодо розвитку інструментів електронної демократії, сутність яких полягає в такому:

- удосконалення системи відкритих даних шляхом формування та розвитку інфраструктури, їх оприлюднення й оновлення, стимулювання на їхній основі розвитку соціально значущих суспільних проєктів та сервісів;

- розвиток та впровадження е-інструментів: е-звернення, е-петиції, бюджет участі («відкритий бюджет», «громадський бюджет»), е-консультації, е-голосування, е-вибори, е-референдум, е-плебісцит, е-парламент, е-правосуддя, е-медіація, е-політичні компанії, е-опитування;

- розвиток е-участі завдяки імплементації е-інструментів;

- підвищення інтерактивності взаємодії органів влади із громадськістю через офіційні вебресурси.

Інструменти електронної демократії, на думку експертів СС, відображені в Рекомендаціях Комітету міністрів Ради Європи [7]. Порівняння переліку цих інструментів з інструментами, що впроваджені в органах влади України, та такими, що застосовуються у країні громадськими організаціями, систематизовано в таблиці 2.

Таблиця 2

Зіставлення електронних інструментів, що реалізуються у країнах СС та в Україні

\begin{tabular}{|c|c|c|}
\hline $\begin{array}{c}\text { Е-інструменти (сфери) електронної } \\
\text { демократії, рекомендовані } \\
\text { до розвитку органами СС }\end{array}$ & $\begin{array}{c}\text { Е-інструменти, що впроваджені } \\
\text { в органах влади України }\end{array}$ & $\begin{array}{c}\text { Е-інструменти, } \\
\text { що застосовуються в Україні } \\
\text { громадськими організаціями }\end{array}$ \\
\hline Е-ходатайства (індивідуальні) & $+($ е-звернення) & + \\
\hline Е-ходатайства (групові) & $+($ е-петиції) & + \\
\hline Е-консультації & + & + \\
\hline «Відкритий бюджет» («громадський бюджет») & - & - \\
\hline Е-опитування & - & - \\
\hline Е-референдум & - & - \\
\hline Е-вибори & - & + \\
\hline Е-голосування & - & + \\
\hline Е-підрахунок голосів & - & + \\
\hline Е-агітація & - & \\
\hline Е-ініціатива & - & + \\
\hline Е-посередництво & & + \\
\hline Е-парламент & - & \\
\hline Е-правосуддя & - & \\
\hline Е-законодавство & - & + \\
\hline
\end{tabular}

Джерело: складено автором.

Більшість інструментів електронної демократії сформовані та розвиваються завдяки ініціативній діяльності громадських організацій, підтримуваних європейськими демократичними рухами, що надають ресурсну підтримку у вигляді грантів. У більшості концептуальних і стратегічних документах сфери електронної демократії задекларована прихильність до європейських цінностей та дотримання вироблених ЄС Рекомендацій. Водночас 
основною рушійною силою залишаються громадські ініціативи, правового механізму забезпечення бюджетного фінансування їхньої діяльності у сфері розвитку електронної демократії натепер немає.

Дослідження інструментів електронної демократії, що реалізуються структурами СС, та їх порівняння з тими, які впроваджуються в Україні, показало, що в нашій країні перевагу віддано таким інструментам, як: електронні звернення, електронні петиції, електронні консультації, «відкритий бюджет» («громадський бюджет») (табл. 2).

Відповідно до ієрархічної структури правового забезпечення розвитку електронної демократії в Україні проведено дослідження щодо належного рівня правового забезпечення найбільш поширених в Україні електронних інструментів, результати якого відображені в табл. 3.

Таблиця 3

Законодавче закріплення розвитку інструментів електронної демократії відповідно до структури правового забезпечення розвитку електронної демократії в Україні

\begin{tabular}{|c|c|c|c|c|}
\hline & \multicolumn{3}{|c|}{ Нормативно-правові акти } \\
\hline $\begin{array}{c}\text { Інструменти електронної } \\
\text { демократії }\end{array}$ & Закони & $\begin{array}{c}\text { Укази, постанови } \\
\text { розпорядження }\end{array}$ & $\begin{array}{c}\text { Нормтивні } \\
\text { документи } \\
\text { місцого рівня }\end{array}$ & + \\
\hline Е-звернення & + & + & + & + \\
\hline Е-петиції & + & + & + \\
\hline Е-консультації & - & - & + \\
\hline $\begin{array}{c}\text { «Відкритий бюджет» } \\
\text { «громадський бюджет») }\end{array}$ & - & - & + \\
\hline Е-ініціатива & - & - & + \\
\hline
\end{tabular}

Джерело: складено автором.

У процесі розкриття сутності наведених у таблиці 3 даних варто зазначити, що правові основи розвитку електронних звернень та петицій визначені у ст. 40 Конституції України: «усі мають право направляти індивідуальні чи колективні письмові звернення або особисто звертатися до органів державної влади, органів місцевого самоврядування та посадових і службових осіб цих органів, що зобов'язані розглянути звернення і дати обгрунтовану відповідь у встановлений законом строк».

Конкретизація правового механізму реалізації електронних звернень міститься в законах України «Про внесення змін до Закону України «Про звернення громадян» щодо електронного звернення та електронної петиції» («Відомості Верховної Ради України», 2015 р., № 35, ст. 341), «Про звернення громадян» № 394/96-ВР від 2 жовтня 1996 р., зі змінами від 22 травня 2018 р. («Відомості Верховної Ради України», 2018 р., № 33, ст. 250), «Про доступ до публічної інформації» № 2939-VI від 13 січня 2011 р., зі змінами від 17 червня 2020 р., «Про електронні довірчі послуги» № 2155-VIII від 5 жовтня 2017 р., зі змінами від 13 лютого 2020 р., та додатково регулюється низкою підзаконних актів. Наведемо лише деякі з них: Указ Президента України № 109/2008 від 7 лютого 2008 р. «Про першочергові заходи щодо забезпечення реалізації та гарантування конституційного права на звернення до органів державної влади та органів місцевого самоврядування»; Указ Президента України № 854/2004 від 31 липня 2004 р. «Про забезпечення умов для більш широкої участі громадськості у формуванні та реалізації державної політики».

Правовий механізм реалізації електронних петицій відображений у згаданих вище законах України і таких нормативних документах, як: Указ Президента України № 523/2015 від 28 серпня 2015 р. «Про Порядок розгляду електронної петиції, адресованої Президентові України»; розпорядження Голови Верховної Ради України № 1494 від 28 жовтня 2015 р. «Про деякі питання організації роботи з реєстрації та супроводження електронних петицій, адресованих Верховній Раді України», зі змінами від 18 лютого 2016 р.; постанова Кабінету Міністрів України № 457 від 22 липня 2016 р. «Про затвердження Порядку розгляду електронної петиції, адресованої Кабінету Міністрів України».

Реалізація механізму електронних консультацій забезпечується постановою Кабінету Міністрів України № 996 від 3 листопада 2010 р. «Порядок проведення консультацій із громадськістю 3 питань формування та реалізації державної політики».

Інструмент електронного голосування станом на 12 серпня 2020 р. реалізується у вигляді пілотного проєкту для формування складу громадських рад.

Аналіз правових механізмів підтримки, розвитку та реалізації інструментів електронної демократії дозволив виявити прогалини, що негативно впливають на розвиток електронної демократії загалом.

Результатом аналізу вказаної законодавчої бази є висновок, що одним із недоліків, що стримує розвиток електронної демократії в Україні, є недосконалість правового механізму забезпечення ресурсної підтримки розвитку електронних інструментів. 
Розвиток інструментів електронної демократії в ресурсному плані натепер переважно забезпечується фінансуванням автоматизації ресурсів державних установ та відомств, що, у свою чергу, не сприяє розвитку вказаних інструментів, а лише забезпечує технічний розвиток цих ресурсів.

Вказаний недолік полягає у відсутності цілісного бачення державою стратегії розвитку електронної демократії як інституції, що покликана підвищити загальний рівень демократизації України. Удосконалення низки інструментів електронної демократії, затверджені Кабінетом Міністрів України у вигляді Плану заходів реалізації Концепції розвитку електронної демократії, містять значну кількість рекомендацій для низки міністерств та відомств, але обов'язковість виділення коштів на виконання вказаних рекомендацій законодавчо не визначена. У кращому разі результатом таких ситуацій є сформовані теоретичні пропозиції вирішення наявних проблем, але їх практична реалізація унеможливлюється через відсутність фінансування.

На місцевому рівні поряд із проблемою відсутності ресурсного забезпечення вказаних інструментів існує проблема їх нормативно-правового забезпечення. Так, розвиток інструментів електронної демократії на місцевому рівні стикається із проблемою відсутності законодавчої бази національного рівня, що має регламентувати реалізацію цих інструментів на регіональному рівні. Нині зазначену проблему місцеві адміністрації вирішують шляхом ухвалення нормативних документів місцевого рівня $[9 ; 10]$.

Серед іншого, на місцевому рівні вкрай важливе питання недостатності вмінь та навичок представників влади та громадськості щодо впровадження та використання інструментів електронної демократії; відсутність мотивації для громадян долучатися до консультацій і обговорень, зокрема і через значний рівень недовіри до влади та демократичних інститутів.

За результатом зіставлення інструментів електронної демократії, що мають законодавче закріплення, та тих, що реалізуються громадськими організаціями (табл. 2), автор дійшов висновку, що державними органами передусім реалізуються формалізовані, тиражовані інструменти електронної демократії, як типові рішення тих інструментів, які показали максимальну ефективність у процесі їх упровадження громадськими організаціями. Характерний для України підхід, коли держава самоусувається від процесу розроблення, тестування інструментів електронної демократії та ресурсного забезпечення цих процесів, залишає це громадським організаціям. Водночас ресурсна підтримка громадських ініціатив забезпечується грантами європейських партнерів. Після успішного запровадження конкретного інструменту силами громадських організацій набутий досвід реалізується у вигляді рекомендацій для Уряду та Парламенту через розроблення відповідних документів, які формують основу нормативних актів.

3 метою розвитку електронної демократії, створення та впровадження ії інструментів низка громадських об’єднань утворили коаліцію, що має назву «Е-демократія». До складу зазначеної коаліції увійшли антикорупційна організація Transparency International, фонди «Відродження» та «Східна Свропа», громадські організації «Реанімаційний пакет реформ» і «Електронна демократія», представники програм EGAP i TAPAS, «Нова країна», Центр розвитку інновацій, Стратегічна група радників з підтримки реформ в Україні (SAGSUR), Oфic ефективного регулювання BRDO і постачальники електронних рішень, серед яких Helsi.me, iGov, ProZorro, YouControl.

Отже, у роботі виокремлено низку недоліків, притаманних правовому механізму публічного управління впровадженням інструментів електронної демократії на національному та місцевому рівнях, а саме:

- недосконалість правового механізму забезпечення ресурсної підтримки розвитку інструментів електронної демократії;

- відсутність цілісного бачення державою стратегії розвитку електронної демократії як інституції;

- перевага розвитку електронних послуг, автоматизації тощо над розвитком залучення громадян до громадсько-політичного життя країни;

- недостатній рівень цифрової та правової грамотності державних службовців щодо розроблення та впровадження законодавчої бази у сфері електронної демократії та ііі інструментів;

- відсутність нормативно-правової бази національного рівня для формування правових засад створення, реалізації та розвитку інструментів електронної демократії на місцевому рівні.

Автором розроблені такі рекомендації органам влади з метою вдосконалення правового механізму публічного управління впровадженням інструментів електронної демократії:

- розробити та затвердити Стратегію розвитку інформаційного суспільства в Україні 2020-2025 рр., визначити електронну демократію одним із пріоритетних напрямів державної політики;

- розробити та затвердити Національну стратегію сприяння розвитку громадянського суспільства в Україні на період до 2025 р. як правове підгрунтя розвитку електронної демократії в Україні;

- розробити доповнення до програми діяльності Уряду з урахуванням міжнародного досвіду та чітким формулюванням завдань профільному міністерству у сфері розвитку електронної демократії як частини розбудови цифрового суспільства в Україні;

- визначити необхідність упровадження та використання інструментів електронної демократії як одного із пріоритетів Національної програми інформатизації; 
- забезпечити законодавчу підтримку механізмів упровадження та розвитку інструментів електронної демократії як на національному, так і на місцевому рівнях шляхом розроблення й ухвалення Стратегії електронної демократії на основі накопиченого досвіду діяльності центральних органів влади та місцевого самоврядування;

- забезпечити ресурсну підтримку правових механізмів реалізації та розвитку інструментів електронної демократії шляхом затвердження Програми заходів із реалізації Стратегії електронної демократії;

- розробити ефективні механізми надання фінансової підтримки громадським ініціативам;

- нормувати законодавство у сфері забезпечення реалізації інструментів електронної демократії на місцевому рівні (електронні звернення, петиції, консультації тощо);

- розробити механізм для впровадження електронного голосування, а також електронного виборчого процесу, електронних референдумів і електронних плебісцитів;

- запровадити посади державних службовців, до компетенції яких входять упровадження та реалізація інструментів електронної демократії;

- забезпечити правову та ресурсну підтримку перепідготовки представників влади в галузі застосування інструментів електронної демократії; ведення роз'яснювальної роботи серед населення щодо доцільності застосування інструментів електронної демократії.

Висновки з дослідження і перспективи подальших розвідок у цьому напрямі:

1. Проаналізовано та систематизовано сукупність основних нормативно-правових актів із питань розвитку інструментів електронної демократії, здійснено ії порівняння з базовими європейськими законодавчими актами.

2. Здійснено порівняльний аналіз застосування інструментів електронної демократії в Україні та ЄС, а також цих інструментів в органах публічної влади й у громадських організаціях.

3. Виокремлено недоліки, притаманні національному правовому механізму публічного управління впровадженням інструментів електронної демократії на загальнодержавному, регіональному та місцевому рівнях.

4. Обгрунтовано рекомендації органам влади щодо вдосконалення чинного правового механізму реалізації інструментів електронної демократії.

Подальші розвідки будуть спрямовані на дослідження організаційних механізмів публічного управління розвитком електронної демократії в Україні.

\section{Список використаних джерел:}

1. Концепція розвитку електронної демократії в Україні, у ред. розпорядження Кабінету Міністрів України № 797-р від 8 листопада 2017 р. URL: https://zakon.rada.gov.ua/laws/show/797-2017-\%D1\%80 (дата 3вернення: 11.08.2020).

2. Головні цілі Міністерства цифрової трансформації України. Міністерство циифрової трансформації Украӥни : офіційний сайт. URL: https://thedigital.gov.ua/ministry (дата звернення: 10.08.2020).

3. Про затвердження Програми діяльності Кабінету Міністрів України, ред. постанова Кабінету Міністрів України № 471 від 12 червня 2020 p. URL: https://zakon.rada.gov.ua/laws/show/471-2020-\%D0\%BF (дата звернення: 09.08.2020).

4. Електронне урядування та електронна демократія : навчальний посібник : у 15-ти ч. / за заг. ред. А. Семенченка, В. Дрешпака. Київ, 2017. Ч. 3 : Електронна демократія: основи та стратегії реалізації / А. Семенченко, А. Серенок. Київ : ФОП Москаленко О.М., 2017. 84 с.

5. Електронне урядування та електронна демократія : навчальний посібник : у 15-ти ч. / за заг. ред. А. Семенченка, В. Дрешпака. Київ, 2017. Ч. 4 : Публічна політика та управління розвитком інформаційного суспільства та електронного урядування / А. Семенченко, А. Серенок. Київ : ФОП Москаленко О.М., 2017. 80 с.

6. Грицяк Н., Соловйов С. Електронна демократія : навчальний посібник. Київ : НАДУ, 2015. 66 с.

7. Recommendation CM/Rec (2009)1 of the Committee of Ministers to member states on electronic democracy (e-democracy). URL: https://wcd.coe.int/ViewDoc.jsp?id=1410627 (дата звернення: 12.08.2020).

8. Використання інструментів електронної демократії органами державної влади та місцевого самоврядування. Державна служба статистики : офіційний сайт. URL: http:/www.ukrstat.gov.ua/operativ/operativ2020/infs/ vied_19.xls (дата звернення: 03.08.2020).

9. Інструменти громадської участі у Львові. Громадська мережа ОПОРА : сайт. URL: https://www.oporaua.org/ news/samovriaduvannia/partysypatsiia/19770-instrumenti-gromadskoyi-uchasti-u-lvovi (дата звернення: 12.08.2020).

10. Інструменти участі в житті громади. Вінницька міська рада : сайт. URL: https:/www.vmr.gov.ua/Lists/ Actual/ShowNews.aspx?ID=1219 (дата звернення: 12.08.2020).

\section{References:}

1. Concept of e-democracy development in Ukraine. Order of the Cabinet of Ministers of Ukraine, November 8 , 2017 № 797-r. Retrieved from: https://zakon.rada.gov.ua/laws/show/797-2017-\%D1\%80 [in Ukrainian]. 
2. Holovni tsili Ministerstva tsyfrovoi transformatsii Ukrainy. (2019). Ofitsiinyi sait Ministerstva tsyfrovoi transformatsii Ukrainy [Official site of the Ministry of Digital Transformation of Ukraine]. Retrieved from: https://thedigital.gov.ua/ministry.

3. On approval of the Program of Activities of the Cabinet of Ministers of Ukraine. Resolution of the Cabinet of Ministers of Ukraine, June 12, 2020 № 471. Retrieved from: https://zakon.rada.gov.ua/laws/show/471-2020-\%D0\%BF.

4. Semenchenko, A.I., Dreshpak, V.M. (2017), Elektronne uriaduvannia ta elektronna demokratiia: navch. posib. Chastyna 3: Elektronna demokratiia: osnovy ta stratehii realizatsii. [E-Government and electronic democracy: tutorial. Part 3: E-democracy: basics and implementation strategies], Kiev: National Academy for Public Administration under the President of Ukraine [in Ukrainian].

5. Semenchenko, A.I., Dreshpak, V.M. (2017), Elektronne uriaduvannia ta elektronna demokratiia: navch. posib. Chastyna 4: Publichna polityka ta upravlinnia rozvytkom informatsiinoho suspilstva ta elektronnoho uriaduvannia. [E-Government and electronic democracy: tutorial. Part 4: Public policy and management of information society and e-government development], Kiev: National Academy for Public Administration under the President of Ukraine [in Ukrainian].

6. Hrytsiak, N.V. Solovjov, S.H. (2015). Elektronna demokratiia [Electronic democracy]. Kyiv: National Academy for Public Administration under the President of Ukraine [in Ukrainian].

7. Recommendation CM/Rec (2009)1 of the Committee of Ministers to member states on electronic democracy (e-democracy). Retrieved from: https://wcd.coe.int/ViewDoc.jsp?id=1410627.

8. Vykorystannia instrumentiv elektronnoi demokratii orhanamy derzhavnoi vlady ta mistsevoho samovriaduvannia. (2020). Derzhavna sluzhba statystyky: ofitsiinyi sait [Official site of State Statistics Service]. Retrieved from: http://www. ukrstat.gov.ua/operativ/operativ2020/infs/vied 19.xls.

9. Instrumenty hromadskoi uchasti u Lvovi. (2020). Sait hromadskoi merezhi OPORA [Official site of the public network OPORA]. Retrieved from: https:/www.oporaua.org/news/samovriaduvannia/partysypatsiia/19770-instrumentigromadskoyi-uchasti-u-lvovi.

10. Instrumenty uchasti $v$ zhytti hromady. (2020). Ofitsiinyi sait Vinnytskoi miskoi rady [Official site of the Vinnytsia City Council]. Retrieved from: https://www.vmr.gov.ua/Lists/Actual/ShowNews.aspx?ID=1219. 